\title{
Spatial concepts of the work environment
}

\author{
Grzegorz Schnotale \\ grzegorz.schnotale@pk.edu.pl \\ Faculty of Architecture, Drawing, Painting and Sculpture Institute, Cracow University of Technology
}

\begin{abstract}
Technological changes and universal digitization have a significant impact on shaping the architectural environment of work, study and innovation. The article discusses the subject of determinants of the spatial concept of the work environment based on BMW office buildings in Munich, Germany. Based on selected examples of office buildings in Munich from the 1960s and contemporary implementations, an attempt was made to describe the factors affecting the functioning of the office work environment and its organization.
\end{abstract}

Key words: architectural work environment, office, innovations, modern work place

\section{Work environment and its functioning}

High access to mobile technologies and modern communication methods increases the possibilities of exchanging ideas in today's world, but also affects high design requirements for work environments. Work in the office is primarily a broadly understood exchange of information. The architecture of the work environment should support and promote processes occurring in a given workplace. To achieve these goals, the diversity of space in the work environment is needed. At the same time, the working environment should be ergonomic. According to Eurofound's European Working Conditions Survey of 2015 ${ }^{1}, 26$ percent of employees believe that their work environment has a negative impact on their well-being. The task of architects is to minimize the negative effects of many hours of work in the office. This issue does not only concern the interior but also many conditions and technical solutions. While designing offices, one should take into account a number of factors that affect the use and impact of the building, while ergonomic functioning in the work environment refers to the workplace perceived in the macro scale - the scale of the entire building and the micro scale considered as customizable individual work places ${ }^{2}$.

The macro scale refers to the supply of energy, heat, adequate air circulation, acoustics, natural lighting, appropriate communication routes and the clarity of the building. All these topics are connected with the costs of functioning the building, energy demand, its impact on the environment and ecological assessment as well as the area per employee. These factors are also determined in various ways by the needs, profile and business goal of a given company. Range of factors on a macro scale takes into account the cooperation of the organization as a structure with the technique needed for the functioning of the building.

The micro scale is perceived subjectively from the perspective of individual workplaces. Functional requirements and the ability to customize them for individual employees' needs are very important in this assessment.

Currently, architectural investments should not only fulfill the technical conditions and be a response to the investor's expectations, but also the quality of the design and construction process is more important. Nowadays, the quality, functioning and impact of buildings are subject to certification processes. Certification affects the value and market competitiveness of the investment, a favorable image in social perception, as well as promoting the high quality of construction. There are several international building certification systems,

1 Eurofound: The European Working Conditions Survey 2015. Available on the Internet: www.eurofound.europa.eu/en/data/europeanworking-conditions-survey [Access: 09.01.2019]

2 Geberzahn W., Der Arbeitsplatz im Büro: Aspekte der modernen Bürogestaltung, Die Bibliothek der Technik, Donauworth, Germany 1994 
one of them is the Sustainable Building Certificate (DGNB - Deutsche Gesellschaft für Nachhaltiges Bauen) ${ }^{3}$. The DGNB certificate is awarded on a 4-point scale: DGNB Bronze, DGNB Silber, DGNB Gold and DGNB Platin. In terms of quality, 6 main thematic sectors are assessed: technology, ecology, economy, social and functional quality of the building, the design and construction process of the building and its impact on the quality of the surrounding environment.

\section{Factors for assessing the concept of the work environment}

The factors for assessing the different spatial concepts of the work environment are divided into three main groups. The first of these are architecture-related factors, such as area, location or transport connections. More subjective references are split in two groups of factors. The division concerns the perspective of the employer and the employee. In the ideal model, the goals of both groups should be convergent, but in practice this is not a simple task, because, for example, employees want flexible working conditions, which to the employer means a reduction in the level of control.

I Factors determined by architectonic conditions:

- Plot: location, terrain conditions, possibility of expansion

- Space use: amount of greenery, density of buildings, parking spaces

- Transport connections: access to public transport

- Service context

II Factors important from the perspective of the Employer:

- Company policy and profile

- Profit

- Development

- Perception of the company, its internal and external marketing objectives

Work efficiency

- Costs of building maintenance, energy efficiency

III Factors important from the employee's perspective:

- Functionality

- Concentration

- Adequate lighting, air and temperature

- Perspective of development

- social facilities

- Identification with the company

When assessing the spatial concepts of a given work environment, it is also important to take into account the distractions in the workplace and their negative impact on employees. The main problems are the noise related to constant phone calls or loud devices and the lack of sound absorbing elements. Lack of proper acoustic barriers between rooms and individual workstations significantly worsens the quality and efficiency of work in the office. Another important factor is proper lighting. Light reflections, too much contrast, inadequate light direction exclude some places as suitable for work. Currently, various combinations of light sources indirectly illuminating the room, eg directed upwards, and giving light directly to the workplace, usually individually adjusted to the needs of the employee, are increasingly used in the design.

Another important factor having a negative impact is the poor microclimate in the building. Poorly adapted temperature or humidity of the room, too small stream of conditioned outdoor air, inappropriate distribution of air in the space of rooms are the most common defects degrading jobs and the well-being of employees. 
In the scope of equipment, attention should be paid to the selection of furniture and equipment. With sedentary work, many workers suffer from backache, headaches and shoulders. The human body is not adapted to being immobile for many hours. An effective solution is to introduce the possibility of lifting the table and the possibility of temporary standing work. The surrounding materials and colors should also not be distracting. Often a good solution is to introduce subdued colors that harmonize with natural greenery. All these elements should harmonize with the organization of work as well as the specificity of the company.

\section{Development of the concept of office space}

The development of BMW office buildings over the years shows the characteristic features of transforming the concept of office space and the factors contributing to these changes. In 1968-1973 an office building was built in Munich BMW-Vierzylinder ${ }^{4}$.

The property is located close to the Munich Olympic Park. Karl Schwanzer was the architect. He created an object in the shape of 4 vertical cylinders placed next to each other. It is a characteristic form that is a dominant in the urban landscape of the city of Munich. In the center of the building there is a communication core, and in 4 cylinders there are open space offices. In this type of office space there are many factors that can contribute to the dissipation of employee concentration. This is not a good arrangement when you need silence and concentration. From the point of view of the employer it is a system in which it is easy to control the progress of work, but when in the late 80 's Frauenhofer Instytutut (IAO) $)^{5}$ conducted a survey in which employees were asked if they would like to continue working in open space offices as many as 94 percent of people answered that they did not like such an office organization, and only 6 percent of respondents wanted to continue working in an open space ${ }^{6}$.

Due to the imperfections of such solutions, already in the 1970s, opportunities to improve working conditions began to be sought. The concept of group offices for about 15 personal teams of employees was proposed. In later years, many ideas were created in which a compromise was sought between work in a group and individual work. In the second half of the 1970s, the first mixed office was established in Scandinavia ${ }^{7}$.

This solution was a compromise between an open space office and individual workplaces. A very good example of the implementation of this concept is the BMW FIZ - Projekthaus project that was created in 2004, which include the BMW brand research and innovation center.

The building is designed on the basis of a square of 100 by $100 \mathrm{~m}$, and its central part is the place of communication and exchange of ideas. The internal organization of space is not typical, because in the middle there is a public workshop surrounded by offices. Thanks to the central part, communication between project teams located on different floors is facilitated. On each floor, employees deal with different technologies, but all stages are visualized in the central part in the form of quickly created models and prototypes. The central workshop is a functional platform for the exchange of knowledge and coordination of all emerging solutions. It also gives designers the opportunity to quickly change the work tool between a virtual model on a computer screen and a physical model. This is an example of how you can combine individual workplaces and open spaces for individual tasks and communication in a team. The four floors of the facility consist of four office spaces for approximately 70 to 120 workplaces where there are also two levels connected by spiral stairs, which facilitates communication between particular project departments ${ }^{8}$. Thanks to this architectural form, the work rooms are clear and support appropriate work organization as well as team and task identification of employees.

The described BMW brand innovation center is one of several buildings within the large premises of the Innovation Center, which comprises office and research buildings. In the urban design project, the entire office complex is planned to be expanded in the near future. The assumption covering a complex of new buildings

4 BMW-Vierzylinder: BMW office building with the shape of four connected cylinders, also called the BMW Tower

5 Frauenhofer IAO: Frauenhofer Institutut für Arbeitswirtschaft und OrganisationInstitute of Economics and Work Organization, Available on the Internet: https://www.iao.fraunhofer.de/[ Access: 26.01.2019]

6 Geberzahn W., Der Arbeitsplatz im Büro: Aspekte der modernen Bürogestaltung, Die Bibliothek der Technik, Donauworth, Germany 1994

7 Geberzahn W., Der Arbeitsplatz im Büro: Aspekte der modernen Bürogestaltung, s.36 Die Bibliothek der Technik, Donauworth, Germany 1994

8 HENN GmbH, Available on the Internet: www.henn.com/de/projects/office/bmw-project-house [Access 26.01.2019] 
is to have an area of approx. $157,000 \mathrm{~m}^{2}$ and will be located in the district of Munich - Milbertshofen. The development and innovation center FIZ is the largest research center of the BMW Group. At several stages of development and expansion until 2050, additional job opportunities will be created for approximately 15,000 employees ${ }^{9}$. The expansion and reconstruction of FIZ is therefore not just an investment in the future of the company, it is also an investment in modern and attractive workplaces. The work environment will be flexible, fill up with spaces that support innovative solutions and give the opportunity to quickly test the software created on the basis of vehicle prototypes in the workshop. The BMW Group in cooperation with the City Urban Planning Department of the City of Munich has launched an architectural competition for the urban design of the entire BMW FIZ. In September 2014, the architectural office HENN ${ }^{10}$ won this competition. The main assumption is the creation of a central spine connecting the entire plot.

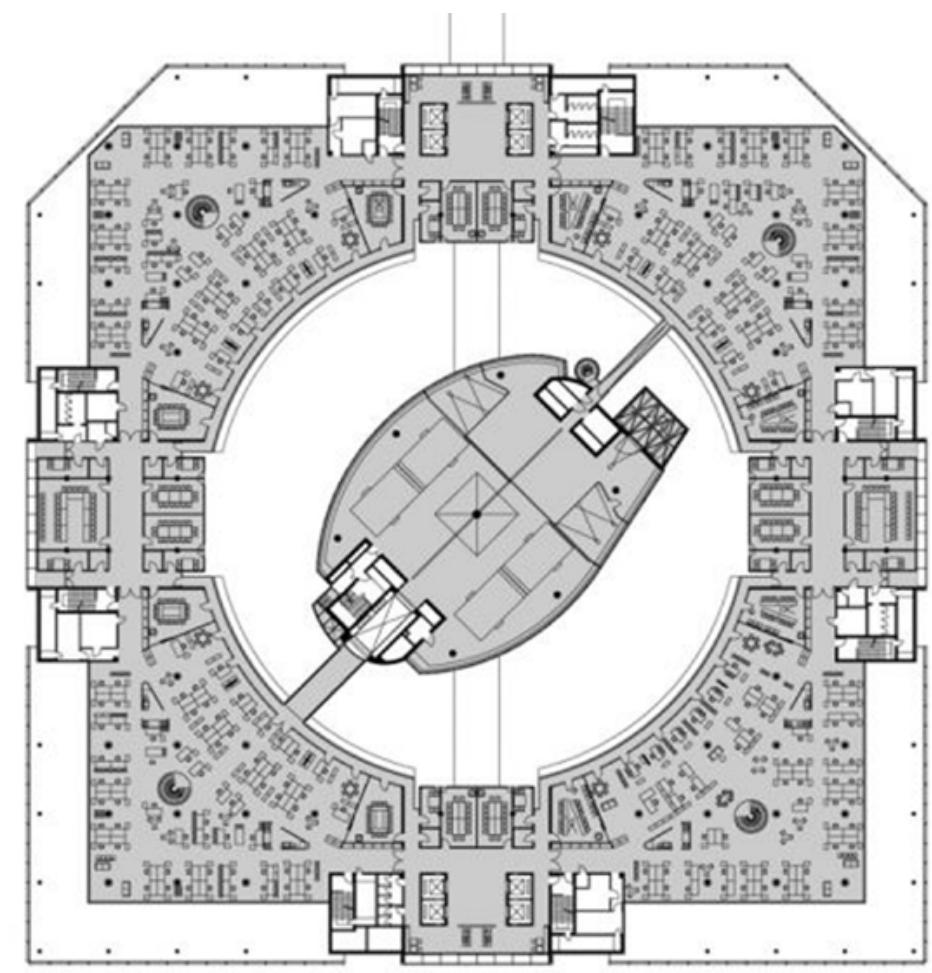

Fig. 1. Plan BMW FIZ Projekthaus, Available on the Internet: http://www.henn.com/de/ projects/office/bmw-projecthouse, [Access: 26.01.2019]

Rzut BMW FIZ Projekthaus, Dostępny w Internecie: http:// www.henn.com/de/projects/ office/bmw-project-house, [Dostęp: 26.01.2019]

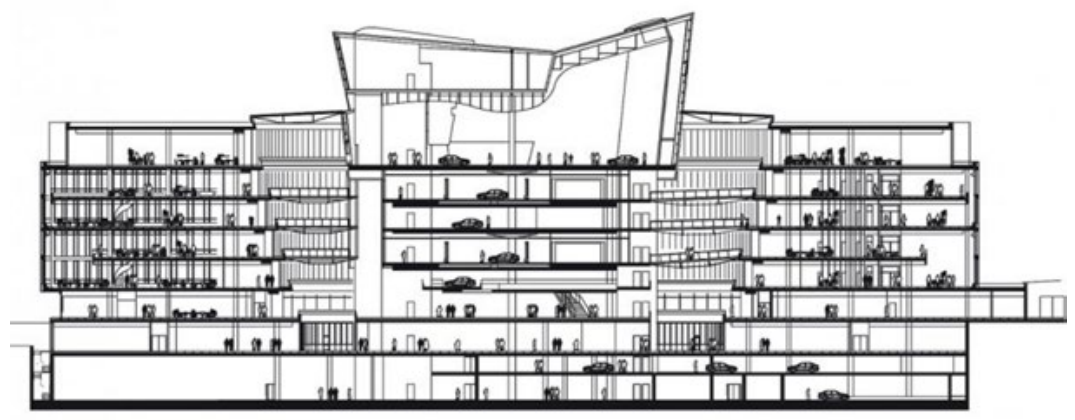

Fig. 2. Section BMW FIZ Projekthaus Available on the Internet: http://www.henn.com/de/ projects/office/bmw-projecthouse [Access: 26.01.2019]

Przekrój BMW FIZ Projekthaus, Dostępny w Internecie: http:// www.henn.com/de/projects/ office/bmw-project-house [Dostęp 26.01.2019]

9 BMW Group, Presseinformation, BMW Group legt Grundstein für den Ausbau ihres Forschungs- und Innovationszentrums FIZ 6.10.2017, Available on the Internet: www.press.bmwgroup.com[Access 26.01.2019] 

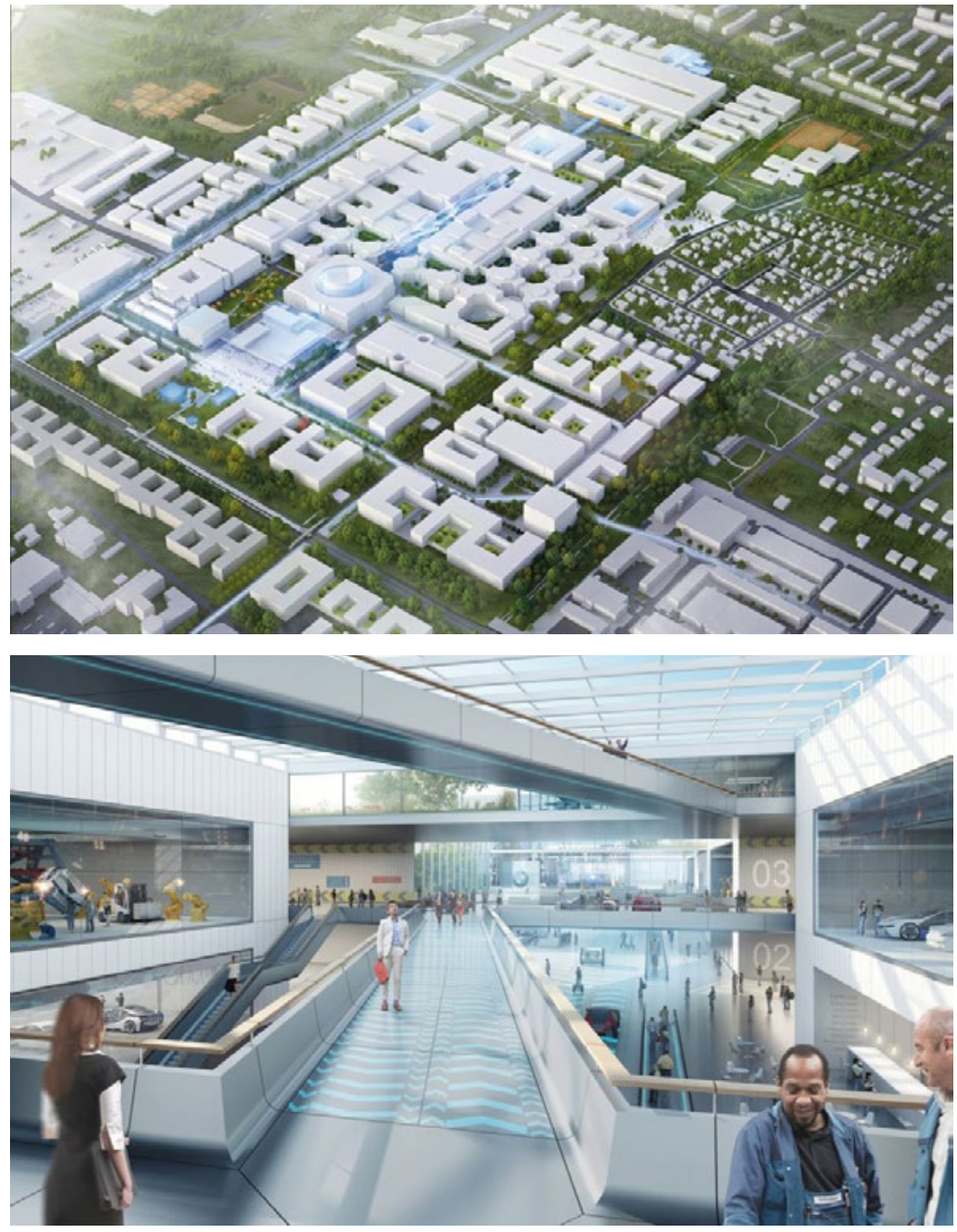

Fig. 3. Visualization showing the entirety of the BMW FIZ. Available on the Internet: http://www.henn.com/ de/projects/industry-urban-design/ bmw-fiz-future [Access 26.01.2019]

Wizualizacja pokazująca całość założenia BMW FIZ. Dostępny w Internecie: http://www.henn.com/de/ projects/industry-urban-design/ bmw-fiz-future [Dostęp 26.01.2019]

Fig. 4. Visualization showing the interior of the BMW FIZ mainline. Available on the Internet: http://www. henn.com/de/projects/industry-urban-design/bmw-fiz-future [Access 26.01.2019]

Wizualizacja pokazująca wnętrze magistrali założenia BMW FIZ. Dostępny w Internecie: http://www.henn.com/ de/projects/industry-urban-design/ bmw-fiz-future [Dostęp 26.01.2019]

The project also provides the creation of a cafe, park and sports fields. This is also aimed at better integration of the entire complex with the urban plan, creating areas for the community of this district of Munich. The central theme for the design of new work opportunity at BMW FIZ is the activity based working.

Under this assumption, free access and the possibility of using a flexible and diversified office environment, which is designed to offer many types of space. The employee can effectively manage time, tools and place of work according to the needs. In the space, for example, a specially silenced chat room is provided, you can have a telephone conversation without disturbing others at work. Stairs and vertical communication, in addition to their standard communication function between floors, are also the social space. The possibility of sitting and interacting with others employees on adapted steps was created. This is an example of a place for informal meetings. There were also designed places for formal meetings at a large design table. Another element of space are concentration workplaces. These are places separated by acoustic walls that fit into standard workplaces and so-called desk sharing, which is shared between employees, not every seat is assigned to only one employee. Through mobile technologies, work does not have to be associated with one permanent place. A very important space is the so-called 'Think Tank', which is the focal point for the development of new ideas, a place for meetings and exchange of experience while creating projects. The best solutions are to be created in such zones, often unconventional and spontaneous. According to this concept, this space should stimulate creativity and offer space for regeneration of strength. Cooperation, accessibility and activity of these slogans well describe current trends on the labor market, where creativity and innovation are the most desired by employers. The work environment created by architects should support these features. 


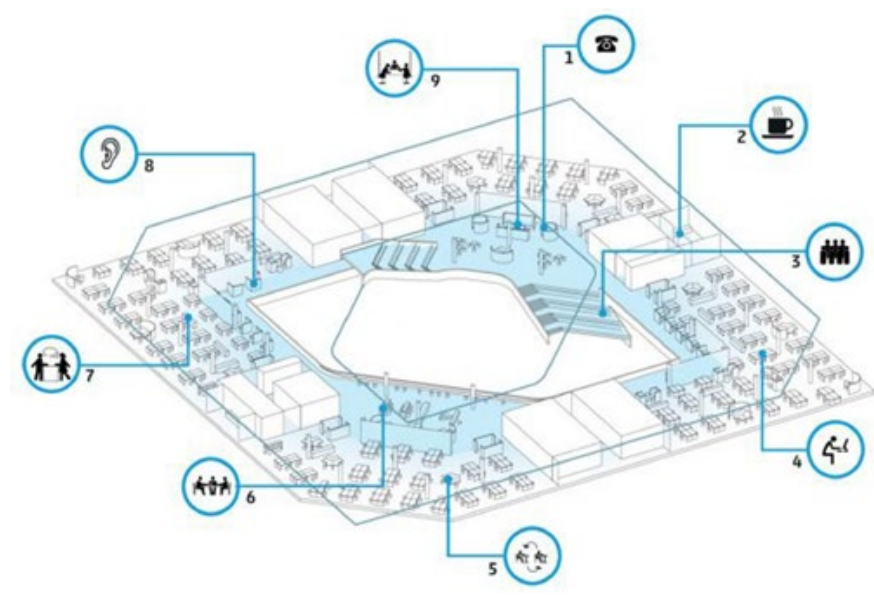

Fig. 5. A schematic diagram of the function of one of the storeys of the BMW FIZ showing the concept of activity based working.

Markings: 1 - A place for calling, 2 - Kitchen, 3 - Stairs with additional seats, $4-$ An individual work place, 5 - Co - Working, 6 - A place for informal meetings, 7 - A place for discussion 8 - A focus area, 9 - A place to look new ideas (Think Tank) source: Henn Jahrbuch 2016, Munich, Germany 2016, p. 54

Schemat funkcji jednej z kondygnacji założenia BMW FIZ pokazujący idee activity based working 1 - Miejsce do telefonowania, 2 - Kuchnia, 3 - Schody z dodatkowymi siedziskami, 4 - Miejsce pracy indywidualnej, 5 - Co - Working, 6 - Miejsce spotkań nieformalnych, 7 - Miejsce dyskusji 8 - Strefa skupienia 9 - Miejsce poszukiwania nowych pomysłów (ang. Think Tank) źródło: Henn Jahrbuch 2016, Monachium, Niemcy 2016, s. 54

According to the survey estimates Hays, Kinnarps, Skanska ${ }^{11}$ in Poland, currently, around 5 percent of offices are flexible workplaces with a dominant open space model of around 75 percent. Aleksandra Krawsz-Kubica, Marketing \& PR Manager, Kinnarps Polska, wrote about office based activities of a business-based nature: $A r-$ rangement of space in the $A B W$ concept is natural. It resembles a home where we have specialized spaces, among which we move during the day according to the type of task - we eat in the dining room, sleep in the bedroom, etc. Similarly at school, where we use special laboratories to learn individual subjects. In the office arranged according to the Internal Security Agency we deal with a flexible work model in which the employee changes the place of performing activities several times during the day according to their nature 12. Work should not be seen as a place where we spend 40 hours a week, but as a process striving to achieve a given goal.

\section{Contemporary trend: Work-Life Balance}

Currently, mobile technologies have made a very large part of the work possible from anywhere, and more often what we are working on is a virtual product. Through the development of electronics, telecommunications and the Internet - an employee does not have to be closely related to a specific physical workplace. Technical capabilities allow for many solutions tailored to the needs of employees and employers. This trend is also associated with the so-called desk-sharing, ie the lack of assigned one work space and the sharing of space at work, depending on the needs. One person can work at home during this time, another at the office, so that in the following days these people will turn into a place of work. As a result, the employer's costs are minimized and the employee is given the opportunity to work flexibly. The Work-Life-Balance slogan was created for the balance between work and private life, which improves the work environment offer by attracting well-qualified staff. According to the "Mobility on a daily basis" message $\mathrm{CBOS}^{13}$ a statistical Pole during the week dedicates 7 hours by car to commuting and 8 hours by public transport. By imposing the price of housing, which is very high in big cities, mobile work is gaining more and more popularity.

\section{Summary}

Technological changes, IT mobility and universal digitization of tasks have a significant impact on shaping the architectural environment of work, study and development. However, there is no one pattern for the perfect

11 Hays, Kinnarps, Skanska, Nie boj sie Activity-Based Working, Warsaw, Poland 2017 Available on the Internet: www.skanska.pl/oferta/biura/ raporty-i-standardy/raport-nie-boj-sie-activity-based-working/ [Access 09.01.2019]

12 Hays, Kinnarps, Skanska, Do not Be Afraid of Activity-Based Working, Warsaw, Poland 2017 Chapter: Culture Activity Based Working, Available on the Internet: www.skanska.pl/oferta/biura/raporty-i-standardy/raportnie-boj-sie-activity-based-working / [Access 09.01.2019] p. 35

13 Kowalczuk K. CBOS Center for Public Opinion Research, Warsaw, Poland Available on the Internet: www.cbos.pl/SPISKOM.POL/2012/K_104_12. PDF [Access 09.01.2019] p.4 
workplace. Arranging a workplace so that a balance between flexibility, individual and team work and the ability to control work progress is possible is also a challenge for specialists in other fields. The most important aspect is the response to users' needs and the reconciliation of often divergent expectations of employees and employers. The arrangement of a modern office should be preceded by an appropriate analysis of the needs of employees, the profile of the company's activity and possible development prospects in the future, as it happens in a large number of projects.

\section{Bibliography}

[1] BMW Group, The Next 100: Ideas, Views and Visions of Tomorrow's World, Munich, Germany 2017

[2] BMW Group, Presseinformation, BMW Group legt Grundstein für den Ausbau ihres Forschungs- und Innovationszentrums FIZ 6.10.2017, Available on the Internet: www.press.bmwgroup.com [Access 09.01.2019]

[3] W. Geberzahn, Der Arbeitsplatz im Büro: Aspekte der modernen Bürogestaltung, Die Bibliothek der Technik, Donauworth, Germany 1994

[4] HENN Gmbh, Jahrbuch, Munich, Germany 2016

[5] HENN GmbH, Available on the Internet: www.henn.com/de/projects/office/bmw-project-house [ Dostęp 26.01.2019]

[6] Hays, Kinnarps, Skanska, Nie bój się Activity-Based Working, Warsaw, Poland 2017 [ Dostęp 09.01.2019] Available on the Internet: www.skanska.pl/oferta/biura/raporty-i-standardy/raport-nie-boj-sie-activity-based-working/

[7] Raport Hays Poland 2016, Nadgodziny - Ile tak naprawde pracujemy i jak to się odbija na naszym zdrowiu, Warsaw, Poland 2016 Available on the Internet:

[8] www.hays.pl/cs/groups/hays_common/documents/digitalasset/hays_1744241.pdf [Access 09.01.2019]

[9] K. Kowalczuk CBOS Centrum Badania Opini Społecznej, Warsaw, Poland August 2012

[10] Available on the Internet: www.cbos.pl/SPISKOM.POL/2012/K_104_12.PDF [Access 09.01.2019],

[11] D. Lorenz, Lean-Office: Die ganzheitliche Optimierung der Büros, Akzent, Munich, Germany 1994

[12] Steelcase WorkSpace Futures, Der Büro-Code:Wie Arbeitskulturen in Europa den Geschäftserfolg beeinflussen, Offizin Chr. Scheufele, Stuttgart, Germany 2008

[13] M. Zirlewagen, Der Arbeitsplatz Der Zukunft, Frankfurt am Main, Henrich Editionen 2017

\section{Koncepcje przestrzenne środowiska pracy}

Streszczenie: Zmiany technologiczne oraz powszechna cyfryzacja wpływają istotnie na kształtowanie środowiska architektonicznego pracy, nauki oraz innowacji. W artykule poruszono tematykę uwarunkowań koncepcji przestrzennych środowiska pracy na podstawie budynków biurowych firmy BMW w Monachium, Niemcy. Na podstawie wybranych przykładów budynków biurowych w Monachium z lat 60. oraz współczesnych realizacji, podjęto próbę opisania czynników wpływających na funkcjonowanie środowiska pracy biurowej i jej organizacji.

Słowa kluczowe: środowisko architektoniczne pracy, biuro, innowacje, nowoczesne miejsce pracy 